\title{
Meningkatkan Hasil Belajar PKn Materi Kebebasan Berganisasi dengan Metode Role Reversal Question pada SiswaKelas V SDN Sisik Timur Tahun Pelajaran 2017/2018
}

\author{
H. JALALUDIN, S,Pd \\ Kepala Sekolah SDN Sisik Timur \\ Kecamatan Pringgarata Kabupaten Lombok Tengah
}

Penelitian ini bertujuan untuk mendeskripsikan peningkatan hasil belajar PKn dengan menggunakan model active learning tipe role reversal question pada siswa kelas V SDN Sisik Timur. Jenis penelitian ini merupakan penelitian tindakan kelas. Subjek penelitian adalah siswa kelas V SDN sisik Timur yang berjumlah 19 siswa. Metode pengumpulan data pada penelitian ini menggunakan tes, Instrumen penelitian berupa tes. Teknik analisis data yang digunakan adalah deskriptif kuantitatif dan kualitatif. Adapun indikator keberhasilan tindakan ditandai dengan $\geq 75 \%$ dari jumlah siswa yang mengikuti proses pembelajaran telah memperoleh nilai $\geq 70$. Berdasarkan anlisa data hasil penelitian menunjukkan adanya peningkatan hasil belajar PKn siswa kelas V SDN Sisik Timur setelah menggunakan model active learning tipe role reversal question baik pada siklus I maupun siklus II. Pada siklus I hasil belajar dari siklus I ke siklus II , menunjukkan peninggkatan hasil yang cukup signifikan dimana nilai rata - rata pada siklus I sebesar 67,63 kemudian meningkat pada siklus II menjadi 86,89 terjadi peningkatan sebesar 19,26 poin ,dan jumlah siswa yang tuntas pada siklus I sebanyak 12 siswa atau dengan persentase sebesar $63 \%$ kemudian pada siklus II jumlah siswa yang tuntas sebanyak 18 orang atau dengan persentase sebesar $95 \%$ terjadi peningkatan sebesar 32 poin, karena ketuntasan klasikal yang dikehendaki terlah tercapai pada siklus II sebesar $95 \%$ maka dengan demikian penelitian dihentikan sampai pada siklus II. Dengan demikian dapat ditarik kesimpulan bahwa pembelajaran model active learning tipe role reversal question, pada pelajaran PKn dapat meningkatkan hasil belajar siswa kelas V di SDN Sisik Timur pada tahun pelajaran 2017 / 2018.

Kata kunci: hasil belajar, $P K n$, model active learning tipe role reversal question

\section{PENDAHULUAN}

Pendidikan merupakan pengalaman belajar yang berlangsung dalam lingkungan dan diperoleh sepanjang hidup. Pendidikan dilakukan oleh keluarga, masyarakat dan pemerintah. Hal ini sesuai dengan pengertian pendidikan menurut Redja Mudyaharjo (2012: 11) yaitu:"pendidikan dapat diartikan usaha sadar yang dilakukan oleh keluarga, masyarakat dan pemerintah melalui kegiatan bimbingan pengajaran atau latihan yang berlangsung di sekolah dan diluar sekolah sepanjang hayat, untuk mempersiapkan peserta didik agar dapat memainkan peranan dalam berbagai lingkungan hidup secara tepat di masa yang akan datang.

Pendidikan diselenggarakan dengan Jurnal Ilmiah Mandala Education memberdayakan semua komponen masyarakat melalui peran serta dalam penyelenggaraan dan pengendalian mutu layanan pendidikan. Menurut UndangUndang Nomor 20 Tahun 2003 pendidikan mempunyai andil yang penting dalam menentukan proses pencapaian tujuan pendidikan nasional yaitu mengembangkan potensi peserta didik agar menjadi manusia yang beriman dan bertaqwa kepada Tuhan Yang Maha Esa, berakhlak mulia, sehat, berilmu, cakap, kreatif, mandiri dan menjadi warga negara yang demokratis serta bertanggung jawab.

Menurut Undang-Undang Nomor 20 Tahun 2003 PKn merupakan mata pelajaran 
diwajibkan untuk jenjang pendidikan dasar, menengah dan mata kuliah wajib untuk pendidikan tinggi. Pada jenjang sekolah dasar PKn diajarkan kepada siswa yang berusia 712 tahun dimana menurut Piaget merupakan fase berkembangan "operasional konkret".

Menurut Piaget (Desmita, 2009: 104) karakteristik anak usia sekolah dasar masuk berada pada tahap operasional konkret, dimana aktivitas mental yang difokuskan pada obyek dan peristiwa yang nyata.. Jika dilihat dari pemikiran dan karakteristik anak usia sekolah dasar, maka dalam pelaksanaan pembelajaran PKn guru dapat merencanakan kegiatan yang mengandung unsur keterlibatan siswa secara langsung.

Dalam pembelajaran PKn di SDN Sisik Timur keterlibatan anak didalam proses pembelajaran tidak tampak sehingga berdampak pada hasil belajar yang rendah. Hal ini dapat dilihat dari hasil ulangan harian pada mata pelajaran PKn yang diikuti oleh 19 orang siswa yang tuntas belajar hanya 8 orang atau persentase sebesar $42 \%$ dan siswa yang belum tuntas sebanyak 11 orang atau dengan persentase sebesar $58 \%$, sementara KKM yang dipatok untuk mata pelajaran PKn di SDN Sisik Timur tahun pelajaran 2017 / 2018 adalah 70, dengan ketuntasan klasikal sebesar $\geq 80 \%$.

Rendahnya hasil belajar siswa seperti yang diuraian diatas disebabkan oleh beberapa paktor diantaranya, metode yang digunakan masih monoton, media pembelajaran kurang menarik sehingga pada saat kegiatan belajar mengajar berlangsung, siswa yang tidak pokus memperhatikan pelajaran, maka guru mencoba untuk merubah metode yang akan digunakan dalam proses belajar mengajar yaitu dengan menerapkan model active learning tipe role reversal question

Model active learning tipe role reversal question dapat diterapkan dalam pembelajaran PKn, karena dapat mengaktifkan siswa terutama dalam kegiatan tanya jawab dengan bertukar peran. Siswa Jurnal Ilmiah Mandala Education dapat berpartisipasi secara langsung, tidak hanya mendengarkan penjelasan materi yang disampaikan oleh guru namun juga berfikir kritis dalam tanya jawab mengenai materi pembelajaran yang diperlajari. Penerapan model active learning tipe role reversal question pada pembelajaran $\mathrm{PKn}$, diharapkan siswa dapat memahami materi yang dipelajari sehingga hasil belajar siswameningkat.

Berdasarkan uraian di atas, peneliti terdorong untuk mengadakan penelitian dengan judul "Meningkatkan Hasil Belajar PKn Materi Kebebasan beroganisasi dengan Menggunakan Model Active Learning Tipe Role Reversal Question Padasiswa Kelas V SDN Sisik Timur Tahun Pelajaran 2017/2018".

\section{RumusanMasalah}

Berdasarkan batasan masalah di atas, maka rumusan masalah dalam penelitian ini adalah bagaimanakahMeningkatkan Hasil Belajar PKn Materi kebebasan berorganisasi dengan Menggunakan Model Active Learning Tipe Role Reversal Question padasiswa KelasV SDN Sisik Timur Tahun Pelajaran $2017 / 2018 ?$.

\section{TujuanPenelitian}

Berdasarkan rumusan masalah di atas, maka tujuan penelitian ini adalah untuk Meningkatkan Hasil Belajar PKn Materi Kebebasan berorganisasi dengan Menggunakan Model Active Learning Tipe Role Reversal Question Padasiswa KelasV Tahun Pelajaran 2017/2018"

\section{ManfaatPenelitian}

Penelitian ini diharapkan dapat memberikan manfaat secara praktis maupun teoritis. Manfaat secaara praktis dapat menjadikan siswa aktifdalam kegiatan pembelajaran sehinggaga hasil belajar ssiswaa meningkat. Sedangkan secara teoritis penelitian ini dapat dijadikan sebagai acuan bagi guru yang lain dalam proses belajar mengajar. Dan dapat dijadikan acuan daam penelitian selanjutnya. 


\section{KAJIAN PUSTAKA}

PendidikanKewarganegaraan

Pendidikan

Kewarganegaraan

merupakan program pendidikan yang menekankan pada pembentukan warganegara agar dapat melaksanakan hak dan kewajiban. Sebagaimana disebutkan dalam Permendiknas Nomor 22 Tahun 2006 yaitu :Mata pelajaran PKn merupakan mapel yang memfokuskan pada pembentukan warganegara yang memahami dan mampu melaksanakan hakhak dan kewajibannya untuk menjadi warga Negara Indonesia yang cerdas, terampil, berkarakter yang diamanatkan oleh Pancasila dan Undang-Undang1945.

Menurut Zamroni (A. Ubaedillah \& Abdul Rozak, 2013: 15) Pendidikan Kewarganegaraan merupakan pendidikan demokrasi yang bertujuan untuk mempersiapkan masyarakat berfikir kritis dan bertindak melalui dengan menanamkan kesadaran bahwa demokrasi adalah bentuk kehidupan yang menjamin hak masyarakat. Sedangkan menurut Soemantri (A. Ubaedillah \& Abdul Rozak, 2013: 15) Pendidikan Kewarganegaraan (civic education) ditandai oleh kegiatan yang sudah diprogramkan oleh sekolah. Kegiatan ini meliputi kegiatan pembelajaran yang dapat menumbuhkan perilaku yang baik. Pendidikan Kewarganegaraan dilakukan dengan kegiatan yang menyangkut pengalaman yang dikaitkan dengan kehidupan nyata seperti kehidupan dalam keluarga danmasyarakat.

Berdasarkan beberapa pengertian di atas dapat disimpulkan bahwa PKn merupakan mata pelajaran yang memfokuskan pada pembentukan warganegara.Dalampembelajarandisekolah,pe mbelajaranPKndapatdikaitkan dengan kehidupan sehari-hari. Dengan mengaitkan pembelajaran PKn dengan kehidupan nytata dapat membentuk perilaku sesuai dengan nilai- nilai yang diharapkan.

\section{Tujuan Pendidikan Kewarganegaraan}

Permendiknas No.22 Tahun 2006 bahwa mata pelajaran PKn bertujuan agar Jurnal Ilmiah Mandala Education peserta didik memiliki kemampuan sebagai berikut : (a) berpikir secara kritis, rasional dan kreatif dalam menanggapi isu kewarganegaraan, (b) berpartisipasi secara aktif dan bertanggung jawab dan bertindak secara cerdas dalam kegiatan bermasyarakat, berbangsa, bernegara, serta anti korupsi, (c) berkembang secara positif dan demokratis untuk membentuk diri berdasarkan karakterkarakter masyarakat indonesia agar dapat hidup bersama dengan bangsa-bangsalain, (d)berinteraksi dengan bangsa-bangsa lain dalam peraturan dunia secara langsung atau tidak langsung dengan memanfaatkan teknologi informasi dankomunikasi.

Untuk mencapai tujuan tersebut maka seyogyanya pembelajaran PKn tidak hanya didominasi dengan ceramah yang dilakukan guru namun melibatkan siswa untuk berpartisispasi secara langsung dalam pembelajaran. Hal ini sesuai dengan pendapat Arthur K. Eliis (Samsuri, 2011: 4) bahwa kata kunci dalam pembelajaran PKn ialah partisipasi. Untuk itu guru dapat membuat rancangan kegiatan yang memunculkan partisipasi siswa dalam belajar sehingga dapat mencapai tujuan PKn yang telah ditentukan.

\section{Pengertian HasilBelajar}

Tujuan akhir dilaksanakannya kegiatan pembelajaran yaitu untuk memperoleh hasil belajar. Menurut Oemar Hamalik (2006: 30) hasil belajar diperoleh jika terjadi perubahan tingkah laku, dari tidak tahu menjadi tahu dan dari tidak mengerti menjadi mengerti. Perubahan tersebut dapat diartikan terjadinya peningkatan dan perkembangan lebih baik dari sebelumnya. Sedangkan menurut Agus Suprijono (2009: 56) hasil belajar merupakan pola perbuatan, nilai-nilai, pengertian-pengertian, sikap-sikap, apresiasi dan keterampilan. Dengan demikian hasil belajar tidak hanya berdasarkan nilai atau skor yang diperoleh dalam kegiatan pembelajaran.

Hasil belajar menurut pemikiran Gagne (M.Thobroni \& Arik Mustofa, 2013: 22) berupa informasi verbal, keterampilan 
intelektual, strategi kognitif, keterampilan motorik, dan sikap. Informasi verbal merupakan kemampuan dalam mengungkapkan pengetahuan baik dam bentuk bahasa, lisan maupun

tertulis. Jika dikaitkan dalam pembelajaran untuk mengetahui pemahaman materi yang dikuasai siswa dapat dengan memberikan pertanyaan secara lisan maupun pertanyaan tertulis. Namun jika siswa dapat menjawab secara tertulis belum tentu dapat menjawab dengan lisan begitu pula sebaliknya untuk itu perlu diperhatikan perkembangan siswa dalam mengukur informasi verbal.

Sedangkan kemampuan intelektual merupakan kegiatan yang melibatkan aktivitas kognitif seperti menganalisis suatu permasalahan dan kemampuan mengkategorikan. Hampir sama dengan kemampuan intelektual, strategi kognitif lebih menekankan pada konsep dalam memecahkan masalah. Kemudian keterampilan motorik merupakan kemampuan melakukan gerak jasmani. Hasil belajar juga mencakup keterampilan dalam bersikap yang dapat dijadikan acuhan dalam berperilaku.

Menurut Bloom (Agus Suprijono, 2009: 6) hasil belajar mencangkup kemampuan kognitif, afektif dan psikomotorik. Kemampuan kognitif meliputi; pengetahuan, pemahaman, penerapan, analisis, sintesa, evaluasi. Kemampuan afektif meliputi; sikap menerima, memberikan tanggapan, penilaian atau penghargaan, organisasi, karakterisasi. Sedangkan kemampuan psikomotor meliputi; meniru, menerapkan, memantapkan, merangkai dan naturalisasi.

Dari pengertian hasil belajar yang sudah dipaparkan di atas dapat dinyatakan bahwa hasil belajar merupakan perubahan sikap dan tingkah laku manusia yang diperoleh dari kegiatan pembelajaran yang melibatkan aspek kognitif, afektif maupun psikomotorik. Hasil belajar di tandai dengan proses tidak tahu menjadi tahu.

Jurnal Ilmiah Mandala Education

\section{Pembelajaran Model Active Learning Tipe Role ReversalQuestion}

Model pembelajaran aktif (active learning) bertujuan untuk membuat aktif dalam aktifitas belajar. Menurut Silberman, Mel (2007: 149) menyebutkan ada 101 pembelajaran aktif salah satunya role reversal question. Role reversal question merupakan kegiatan pembelajaran aktif yang menekankan pada aktivitas tanya jawab dengan pertukaran peran. Jika guru bertukar peran menjadi siswa maka guru mengajukan pertanyaan dan siswa mencoba menjawab pertanyaan. Begitupula sebaliknya jika siswa yang mengajukan pertanyaan maka guru yang menjawab.

Dari kegiatan tersebut diketahui bahwa terdapat kegiatan yang dilakukan siswa untuk aktif dalam pembelajaran. Terjadi interaksi antara guru dengan siswa, maupun siswa dengan siwa lain dalam kegiatan tanya jawab. Sehingga aktifitas pembelajaran tidak hanya guru memberikan ceramah mengenai materi pelajaran. Siswa juga latih untuk berani mengajukan pertanyaan serta memberikan pendapat, serta berfikir kritis dalam menjawab pertanyaan.

\section{Langkah-Langkah Model Active Learning Tipe Role Reversal Question}

Langkah-langkah pembelajaran model active learning tipe role reversal question menurut Silberman (2007: 149-150) antaralain: (a) Susunlah pertanyaan yang akan anda kemukakan tentang materi pelajaran seolah-olah anda seorang pesertadidik, (b) Pada awal sesi pertanyaan, umumkan kepada peserta didik bahwa anda akan menjadi peserta didik dan peserta didik secara kolektif menjadi anda. Beralihlah lebih dahulu ke pertanyaananda, (b) Berlakukah argumentatif, humoris, atau apa saja yang dapat membawa mereka pada perdebaran dan menyerang anda dengan jawaban- jawaban, (c) Memutar peranan beberapa kali akan tetap membuat peserta didik anda pada pendapat mereka dan mendorongnya untuk melontarkan pertanyaan miliksendiri. 
Dalam pelaksanaan pembelajaran menggunakan model active learning tipe role reversal question guru bersikap argumentatif, serta merespon dengan memberikan umpan balik terhadap jawaban yang disampaikan siswa. Setiap ada ketidaksesuaian jawaban yang disampaikan siswa maka guru dapat memberikan pemahaman tentang jawaban yang benar.

\section{Kelebihan dan Kekurangan Model Active Learning Tipe Role Reversal Question}

Berdasarkan pembahasan yang sudah dipaparkan diatas, model active learning tipe role reversal question memiliki kelebihan antara lain; (a) Proses belajar mengajar berpusat padasiswa, (b) Siswa aktif dalam pembelajaran karena siswa terlibat langsung dalam pelajaran, (c) Kegiatanpembelajaranmenjadikansiswaberfiki rkritisdalam menjawab pertanyaan guru, (d) Proses pembelajaran menarik, sebab siswa tidak hanya mendengar tetapi juga mengalami kejadiantersebut, (e) Melatih keberanian siswa dalam bertanya dan menjawabpertanyaan, (f) Menciptakan kerjasama antar siswa dalam kegiatanpembelajaran, (g) Siswa berpartisipasi dalam kegiatanpembelajaran, (h) Menumbuhkan sikap tanggung jawab sebagai individu dankelompok, Menciptakan minat dan motivasi pembelajaran.

Sedangkan kekurangan dari model active learning tipe role reversal question yaitu : (a) Membutuhkan waktu lama dalam mempersiapkan pengkondisian kelas untuk memahamkan siswa bertukar peran dengan guru, (b) Dibutuhkan waktu tambahan agar memeroleh hasil yang maksimal dalam penyampaianpembelajaran, (c) Topik pembahasan materi menjadi luas jika pertanyaan yang muncul tidak sesuai dengan materi yang sedangdipelajari, (d) Memerlukan keterampilan guru dalam mengelolakelas, (e) Memunculkan keatifan siswa tidaklah mudah, untuk itu diperlukan teknik dan keterampilan agar siswa aktif dalammembelajaran.

Jurnal Ilmiah Mandala Education

\section{METODE PENELITIAN JenisPenelitian}

Penelitian ini merupakan penelitian tindakan kelas (classroom action research). Menurut Suharsimi Arikunto,dkk (2007: 3) penelitian tindakan kelas merupakan suatu pencermatan dari kegiatan pembelajaran berupa tindakan yang sengaja dimunculkan dan terjadi pada sebuah kelas secara bersama, jenis penelitian tindakan kelas yang digunakan dalam penelitian ini adalah kolaboratif, dalam artian peneliti terlibat dalam kegiatan yang digunakan sebagai sumber data penelitian (Sugiono, 2010: 310).

\section{Desain Penelitian}

Menurut Suharsimi Arikunto (2007: 16) penelitian tindakan kelas dilakukan sekurang-kurangnya dalam dua siklus tindakan yang berurutan. Ada beberapa ahli yang mengemukakan model penelitian tindakan, namun secara garis besar terdapat empat tahapan yang dilalui yaitu (1) perencanaan, (2) pelaksanaan,pengamatan dan (4) refleksi. Adapun model dan penjelasan untuk masing- masing tahapberikut.

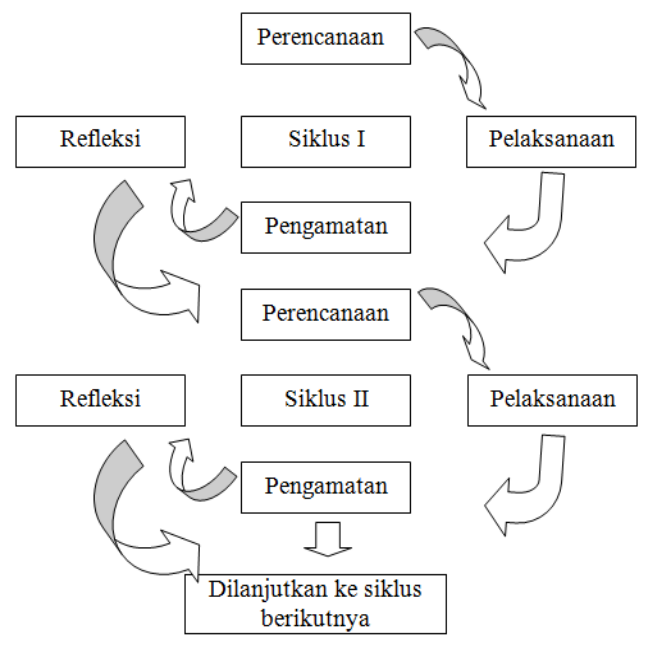

Gambar 2. Desain Penelitian Tindakan Kelas (Suharsimi, 2007: 16)

Penelitian ini dilakukan dalam bentuk siklus, setiap siklus terdiri dari perencanaan, tindakan, observasi serta refleksi. 


\section{Lokasi dan Waktu Penelitian}

Lokasi penelitian yang digunakan dalam penelitian ini di SDN Sisik Timur Desa Sintung Kecamatan Pringgarata, Waktu yang digunakan adalah bulan juli sampai dengan bulan September 2017 pada semester ganjil tahun pelajaran 2017 / 2018.

\section{Subjek Dan ObjekPenelitian}

Subyek penelitian ini adalah siswasiswi kelas V SDN Sisik Timur yang berjumlah 19 orang terdiri dari 12 orang siswa laki - laki dan 7 orang siswa perempuan. Sedangkan obyek penelitian ini adalah hasil belajar PKn menggunakan model active learning tipe role reversalquestion.

\section{Instrumen Pengumpulan Data}

Instrumen pengumpulan data yang digunakan dalam penelitian tindakan kelas ini meliputi tes, dalam penelitian ini tes digunakan ialah tes tertulis dengan bentuk objektif (pilihan ganda).

\section{Teknis Analisis Data}

Dalam penelitian tidakan kelas (PTK) analisis data diarahkan untuk mencari dan menemukan upaya yang dilakukan guru dalam meningkatkan hasil belajar siswa terutama pada mata pelajaran PKn dengan menuggunakan model active learning tipe role reversal question. Dengan demikian analisis data yang digunakan dalam penelitian kelas dapat menggunakan analisis kuantitatif dan kualitatif.

Data kuantitatif diperoleh dari hasil belajar dan aktivitas siswa. Rumus statistik yang digunakan untuk mengolah hasilbelajarsiswa menggunakan statistik sederhana yaitu menggunakan rumus mencari skor rerata kelas. Skor yang diperoleh dengan menjumlahan seluruh skor siswa dan dibagi dengan jumlah siswa. Rumus tersebut sebagai

berikut. $\quad \bar{X}=\frac{\sum X}{\sum N}$

$\overline{\mathrm{x}}=$ skor rata-rata

$\sum \mathrm{x}=$ jumlah skor siswa

$\sum \mathrm{N}=$ jumlah siswa

Untuk menghitung persentase hasil belajar dan aktivitas siswa menggunakan rumus

Jurnal Ilmiah Mandala Education sebagai berikut.

Persentase $(\%)=\frac{\text { Jumlah skor yang diperoleh }}{\text { Jumlah skor maksimal }} \times 100 \%$

\section{HASIL PENELITIAN}

Siklus I

Berdasarkan analisa data dapat dijelaskan bahwa hasil belajar siswa dengan menggunakan model active learning tipe role reversal question, rata - rata hasil belajar siswa sebesar 67,63, kemudian jumlah siswa yang tuntas belajar sebanyak 12 orang atau dengan persentase sebesar $63 \%$, dan jumlah siswa yang belum tuntas sebanyak 7 orang atau dengan persentase sebesar $37 \%$, ini terjadi karena siswa masih belum terbiasa diajarkan dengan model model active learning tipe role reversal question, maka dengan demikian penelitian dilanjutkan ke siklus berikutnya.

siklus II

Berdasarkan analissis hasil belajar siswa pada siklus II menunjukkan hasil yang signifikan dengan menggunakan model active learning tipe role reversal question, rata - rata hasil belajar siswa sebesar 86,89, kemudian jumlah siswa yang tuntas belajar sebanyak 18 orang atau dengan persentase sebesar $95 \%$, dan jumlah siswa yang belum tuntas sebanyak 1 orang atau dengan persentase sebesar $5 \%$, ini terjadi karena siswa masih tersebut jarang masuk sekolah dengan model model active learning tipe role reversal question, pada siklus II , ketuntasan klasikal yang dipersyaratkan sebesar $\geq 80 \%$ sudah tercapai maka dengan demikian penelitian dihentikan sampai pada siklus II..

\section{Pembahasan}

Penelitian ini ini dilaksanakan dari bulan juli sampai dengan bulan September 2017 pada semester ganjil tahunpelajaran 2017 / 2018 , dengan jumlah sabyek penelitian sebanyak 19 orang terdiri dari dari 12 orang siswa laki - laki dan 7 orang siswa perempuan. Hasil belajar siswa terus menunujukkan peningkatan hasil yang cukup signifikan , Berdasarkan tabel yang tertera 
diatas dapat dilihat hasil belajar siswa dengan menggunakan model active learning tipe role reversal question, rata - rata hasil belajar siswa sebesar 67,63, kemudian jumlah siswa yang tuntas belajar sebanyak 12 orang atau dengan persentase sebesar $63 \%$, dan jumlah siswa yang belum tuntas sebanyak 7 orang atau dengan persentase sebesar $37 \%$, ini terjadi karena siswa masih belum terbiasa diajarkan dengan model model active learning tipe role reversal question, maka dengan demikian penelitian dilanjutkan ke siklus berikutnya.

Hasil belajar siswa siklus II menunjukkan hasil yang cukup signifikan dengan menggunakan model active learning tipe role reversal question, rata - rata hasil belajar siswa sebesar 86,89, kemudian jumlah siswa yang tuntas belajar sebanyak 18 orang atau dengan persentase sebesar $95 \%$, dan jumlah siswa yang belum tuntas sebanyak 1 orang atau dengan persentase sebesar $5 \%$, ini terjadi karena siswa masih tersebut jarang masuk sekolah dengan model active learning tipe role reversal question, pada siklus II , ketuntasan klasikal yang dipersyaratkan sebesar $\geq 80 \%$ sudah tercapai maka dengan demikian penelitian dihentikan sampai padasiklus II.

$$
\text { Jika dilihat perbandingan hasil }
$$

beelajar dari siklus I ke siklus II , menunjukkan peninggkatan hasil yang cukup signifikan dimana nilai rata - rata pada siklus I sebesar 67,63 kemudian meningkat pada siklus II menjadi 86,89 terjadi peningkatan sebesar 19,26 poin ,dan jumlah siswa yang tuntas pada siklus I sebanyak 12 siswa atau dengan persentase sebesar $63 \%$ kemudian pada siklus II jumlah siswa yang tuntas sebanyak 18 orang atau dengan persentase sebesar $95 \%$ terjadi peningkatan sebesar 32 poin ,begitu juga dengan jumlah siswa yang tidak tuntas pada siklus I sebanyak 7 orang atau dengan persentase sebesar $37 \%$ kemudian terjadi penurunan persentase pada siklus II menjadi 1 orang anak yang tidak tuntas belajar atau dengan persentase sebesar Jurnal Ilmiah Mandala Education
$5 \%$, dan ketuntasan klasikal yang dicapai pada siklus II sebesar $95 \%$ maka dengan demikian pada siklus II semua indikator yang dipersyaratkan sudah tercapai sehingga penelitian dihentikan sampai pada siklus II.

Dengan demikian dapat ditarik kesimpulan bahwa dengan menggunakan model active learning tipe role reversal question, pada pelajaran $\mathrm{PKn}$ dapat meningkatkan hasil belajar siswa kelas V di SDN Sisik Timur pada tahun pelajaran 2017 / 2018.

\section{KESIMPULAN}

Berdasarkan hasil penelitian dan pembahasan dapat disimpulkan bahwa pembelajaran PKn mengunakan model active learning tipe role reversal question dapat meningkatkan hasil belajar siswa kelas V SDN Sisik Timur ini terlihat dari hasil belajar siswa dari siklus I menuju siklus II , yang dilaksanakan dari bulan juli sampai dengan bulan September 2017 , dengan jumlah sabyek penelitian 19 orang siswa.

Jika dilihat perbandingan hasil beelajar dari siklus I ke siklus II , menunjukkan peninggkatan hasil yang cukup signifikan dimana nilai rata - rata pada siklus I sebesar 67,63 kemudian meningkat pada siklus II menjadi 86,89 terjadi peningkatan sebesar 19,26 poin ,dan jumlah siswa yang tuntas pada siklus I sebanyak 12 siswa atau dengan persentase sebesar $63 \%$ kemudian pada siklus II jumlah siswa yang tuntas sebanyak 18 orang atau dengan persentase sebesar $95 \%$ terjadi peningkatan sebesar 32 poin ,begitu juga dengan jumlah siswa yang tidak tuntas pada siklus I sebanyak 7 orang atau dengan persentase sebesar $37 \%$ kemudian terjadi penurunan persentase pada siklus II menjadi 1 orang anak yang tidak tuntas belajar atau dengan persentase sebesar $5 \%$, dan ketuntasan klasikal yang dicapai pada siklus II sebesar $95 \%$ maka dengan demikian pada siklus II semua indikator yang dipersyaratkan sudah tercapai sehingga penelitian dihentikan sampai pada siklus II.

Dengan demikian dapat ditarik 
kesimpulan bahwa dengan menggunakan model active learning tipe role reversal question, pada pelajaran PKn dapat meningkatkan hasil belajar siswa kelas V di SDN Sisik Timur pada tahun pelajaran 2017 / 2018.

\section{SARAN}

Berdasarkankesimpulanhasilpenelit ianyangtelahdikemukakan sebelumnya, maka terdapat beberapa saran sebagaiberikut;

Siswa hendaknya lebih berani dalam mengemukakan pendapat, pertanyaan dan ide yang dimiliki tidak hanya dalam pelajaran $\mathrm{PKn}$ saja namun pada mata pelajaran yang lain. Hasil belajar PKn siswa telah mengalami peningkatan setelah diberi tindakan menggunakan model active learning tipe role reversal question, oleh karena itu disarankan kepada siswa agar mempertahankan dan lebih rajin belajar sehingga hasil belajar yang diperoleh selalu baik.

Guru diharapkan dapat menggunakan model active learning tipe role reversal question dalam meningkatkan hasil belajar siswa pada mata pelajaran lain. Selain itu guru diharapkan dapat mengembangkan model active learning tipe role reversal question untuk menunjang kegiatan pembelajaran, sehingga dapat mengoptimalkan potensi yang dimiliki siswa dalam memperoleh ilmu.

Pihak sekolah diharapkan memberikan pelatihan kepada guru tentang menerapkan kegiatan pembelajaran yang inovatif seperti model active learning tipe role reversal question. Sekolah juga menyediakan referensi buku tentang pembelajaran yang baik serta sarana penunjang

\section{DAFTAR PUSTAKA}

Agus Suprijono. (2009). Cooperative Learning: Teori dan Aplikasi PAIKEM. Yogyakarta :Pustaka Pelajar

A.Ubaedillah \& Abdul Rozak. (2013). Pendidikan Kewarganegaraan (Civic Education): Pancasila, demokrasi, hak Jurnal Ilmiah Mandala Education asasi manusia dan masyarakat madani. Jakarta: ICCE UIN Syarif Hidayatullah

Ari Samandhi. (2009). Pembelajaran Aktif (Active Learning). Jakarta: Teaching Improvement Worshop Enginering Education Develompment Project.

Baharudin \& Esa Nur Wahyuni. (2009). Teori Belajar dan Pembelajaran. Yogyakarta: Ar-Ruzz Media.

Desmita. (2009). Psikologi Perekembangan Peserta Didik: Panduan Bagi Orang Tua Dan Guru Dalam Memahami Psikologi Anak Usia SD, SMP, SMA. Bandung: PT. Remaja Rosdakarya.

Diana Mutiah. (2010). Psikologi Bermain Anak Usia Dini. Jakarta: Kencana Prenada

Endang Poerwanti dkk. (2008). Asesmen Pembelajaran SD. Jakarta: Dirjen Dikti. Hamruni. (2011). Strategi Pembelajaran. Yogyakarta: Insan Madani.

Hiszyam Zaini. (2008). Strategi Pembelajaran Aktif. Yogyakarta: Insan Madani. Hollingsworth, Pat \& Gina Lewis. (2008). Pembelajaran Aktif: MeningkatkanKeasyikan Kegiatan Di Kelas. Penerjemah: Dwi Wulandari. Jakarta: Indeks.

Moh. Sholeh Hamid. (2011). Metode Edutaiment. Yogyakarta: Diva Press. Redja Mudyahardjo. (2012). Pengantar Pendidikan. Jakarta: Rajawali Pers.

Muhammad Thobroni \& Arik Mustofa. (2013). Belajar \& Pembelajaran: Pengembangan Wacana Dan Praktik Pembelajaran Dalam Pembangunan Nasional . Yogyakarta:Ar-Ruzz Media.

Muhibinsyah. (2011). Psikologi Belajar. Jakarta: Rajawali Press.

Nana Sudjana. (2011). Penilaian Hasil Proses Belajar Mengajar. Bandung: PT Remaja Rosda Karya.

Naswatul Lailah. (2003). Konsep Dasar Active Learning Dan Relevansinya Dengan Pengajaran Muhadatsah. Yogyakarta: Universitas Islam Negeri Yogyakarta. 
Oemar Hamalik. (2006). Proses Belajar Mengajar. Bandung: Bumi Aksara. Permendiknas No.22 Tahun 2006 tentang Standar Isi untuk Satuan Pendidikan

Redja Mudyahardjo. (2012). Pengantar Pendidikan. Jakarta: Rajawali Pers.

Ibrahim dan Nana Syaodih Sukmadinata. (2010). Perencanaan Pengajaran. Jakarta: RinekaCipta.

Rusman.(2010).Model-ModelPembelajaran: Mengembangkan Profesionalisme Guru. Jakarta : Rajawali Press.

Saiful Bahri Djamarah. (2011).Psikologi Belajar. Jakarta: Rineka Cipta.

Silberman, Mel. (2007). Active Learning: 101 Strategi Pembelajaran Aktif.Penerjemah: Sarjuli. Yogyakarta: Insan Madani.

Sugiyono. (2009). Metode Penelitian Pendidikan Pendekatan Kuantitatif, Kualitatif, dan $R \quad \& \quad D$. Bandung: Alfabeta.

Sugihartono, dkk. (2007). Psikologi Pendidikan. Yogyakarta: UNY Press. Suharsimi Arikunto. (2007).Penelitian Tindakan Kelas. Jakarta: BumiAksara 